Juli-Desember 2021: 169 - 188

\title{
ANALISIS PENGARUH RELIGIOSITAS, PENDAPATAN, DAN SIKAP TERHADAP MINAT MEMBAYAR ZAKAT MASYARAKAT MUSLIM KABUPATEN SEMARANG DENGAN PENGETAHUAN SEBAGAI VARIABEL MODERATING
}

\author{
Nio Okta Nugraheni \\ Institut Agama Islam Salatiga \\ Email: niookta1234@gmail.com \\ Ahmad Mifdlol Muthohar \\ Institut Agama Islam Salatiga \\ Email:mifdlol@gmail.com
}

\begin{abstract}
This study aims to determine the effect of religiosity, income, and attitude, with knowledge as a moderating variable, having an effect either simultaneously or partially on the interest in paying zakat of the Muslim community in Semarang Regency. This research belongs to the type of quantitative research. In this study, the population of the Muslim community in Semarang Regency was used. With a purposive sampling technique, and a sample of 100 respondents was taken. Meanwhile, the analytical technique used in this research is descriptive technique, as well as hypothesis testing technique using multiple linear regression analysis. The results of this study indicate that: religiosity (X1) has no effect on the interest of the Muslim community in Semarang Regency to pay zakat. Income (X2) has a positive and significant effect on the interest of the Muslim community in Semarang Regency to pay zakat. Attitude (X3) has no effect on the interest of the Muslim community in Semarang Regency to pay zakat. Religiosity is moderated by knowledge (X1xZ) and knowledge affects religiosity on the interest in paying zakat of the Muslim community in Semarang Regency. Income is moderated by knowledge $(X 2 x Z)$ and knowledge affects income on the interest in paying zakat of the Muslim community in Semarang Regency. Attitudes are moderated by knowledge $(X 3 x Z)$ and knowledge affects attitudes towards the interest in paying zakat of the Muslim community in Semarang Regency.
\end{abstract}

Keywords: Knowledge, Income, Attitude, Religiosity, Interest in Paying Zakat

\begin{abstract}
Abstrak
Penelitian ini bertujuan untuk mengetahui pengaruh religiositas, pendapatan, dan sikap, dengan pengetahuan sebagai variabel moderating, berpengaruh baik secara simultan ataupun parsial terhadap minat membayar zakat masyarakat muslim kabupaten semarang. Penelitian ini termasuk ke dalam jenis penelitian kuantitatif. Dalam penelitian ini menggunakan populasi masyarakat muslim Kabupaten Semarang. Dengan teknik pengambilan sampel purposive sampling, dan diambil sampel sejumlah 100 responden. Sedangkan dalam teknik analisis yang digunakan dalam penelitian ini ialah dengan teknik deskriptif, serta teknik pengujian hipotesis dengan menggunakan analisis regresi linierberganda. Hasil dari penelitian ini menunjukkan bahwa: religiositas (X1) tidak berpengaruh terhadap minat masyarakat muslim Kabupaten Semarang untuk membayar zakat. Pendapatan (X2) berpengaruh positif dan signifikan terhadap minat masyarakat
\end{abstract}


muslim Kabupaten Semarang untuk membayar zakat. Sikap (X3) tidak berpengaruh terhadap minat masyarakat muslim Kabupaten Semarang untuk membayar zakat. Religiositas di moderasi oleh pengetahuan (X1xZ) dan pengetahuan mempengaruhi religiositas terhadap minat membayar zakat masyarakat muslim Kabupaten Semarang. Pendapatan di moderasi oleh pengetahuan (X2xZ) serta pengetahuan mempengaruhi pendapatan terhadap minat membayar zakat masyarakat muslim Kabupaten Semarang. Sikap di moderasi oleh pengetahuan $(\mathrm{X} 3 \mathrm{xZ})$ dan pengetahuan mempengaruhi sikap terhadap minat membayar zakat masyarakat muslim Kabupaten Semarang.

Kata kunci: Pengetahuan, Pendapatan, Sikap, Religiositas, Minat Membayar Zakat.

\section{Pendahuluan}

Zakat adalah salah satu bentuk ibadah kepada Allah setelah manusia diberi keberhasilan dalam bekerja atau mencari nafkah dengan melimpahnya harta benda yang dimilikinya. Zakat merupakan salah satu Rukun Islam yang ke empat. Zakat hukumnya wajib berdasarkan alquran dan sunah yang harus dijalankan oleh umat Islam

1. Zakat juga memiliki konsep tolong menolong, karena zakat juga termasuk ibadah wajib bagi umat Islam seperti zakat, haji, dan puasa yang telah diatur berdasarkan alquran dan sunah. Ditinjau dari segi bahasa, kata zakat memiliki beberapa arti, yaitu al-barakatu "keberkahan", al-namaa "pertumbuhan dan perkembangan", ath-tahartu "kesucian" dan ash-shahalu "keberesan". Sedangkan dilihat dari Kamus Besar Bahasa Indonesia zakat berarti jumlah harta tertentu yang wajib dikeluarkan oleh orang yang beragama Islam dan diberikan kepada orang - orang yang membutuhkannya ${ }^{2}$.

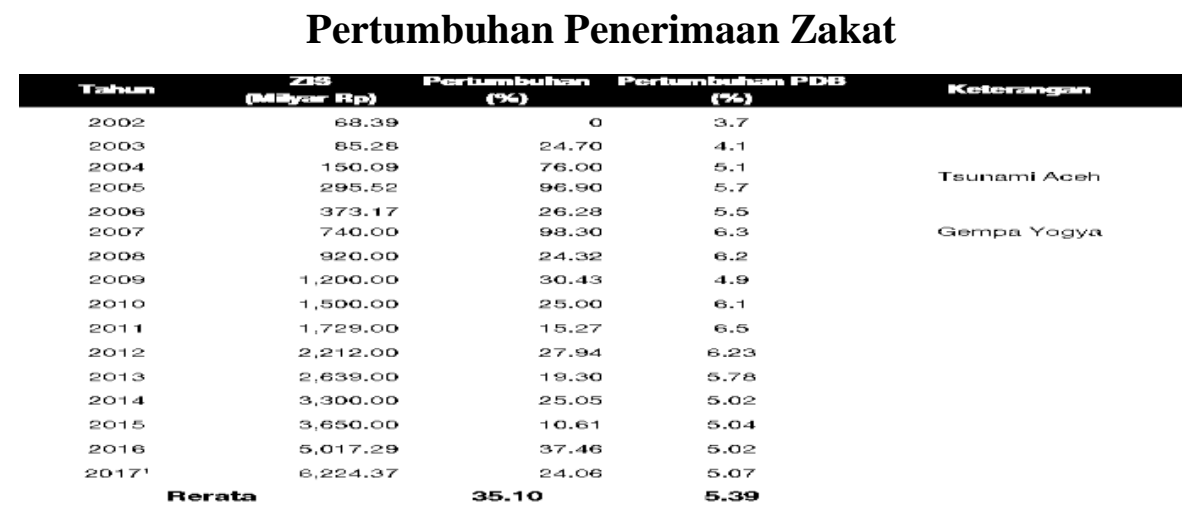

Sumber: Statistik Zakat Nasional

Dilihat dari data di atas pertumbuhan penerimaan zakat dari masyarakat ke Badan Amil Zakat dari tahun 2002 - 2017 dari tahun ketahun semakin meningkat. Dengan demikian bisa disimpulkan bahwa pertumbuhan penerimaan 
Juli-Desember 2021: 169 - 188

zakat sangat baik karena selalu meningkat di setiap tahunnya. Indonesia seharusnya mempunyai potensi yang sangat besar dalam hal zakat, namun zakat yang terkumpul saat ini belum sebanding dengan potensi yang ada. Hal tersebut disebabkan karena kurangnya kesadaran masyarakat berzakat maal, terutama berzakat di lembaga zakat.

Zakat jika dikelola dengan baik berpotensi besar untuk meningkatkan perekonomian umat Islam, bukan hanya umat Islam namun juga seluruh warga yang kurang mampu. Meningkatnya dunia zakat tidak terlepas dari peran muzaki atau bisa disebut juga sebagai sekelompok orang yang membayar zakat, karena mereka sudah memberikan kepercayaannya kepada lembaga zakat untuk menyalurkan sebagian hartanya kepada orang yang membutuhkan. Oleh karena itu dalam pelaksanaan zakat di Negara Indonesia sendiri masih sangat kurang optimal karena ketika tingkat kesadaran masyarakat muslim untuk berzakat masih sangat rendah. Masih rendahnya kesadaran dalam membayar zakat khususnya di lembaga zakat digolongan masyarakat muslim terjadi secara nasional sehingga realitas masih rendahnya berzakat di kalangan umat khususnya berzakat di lembaga zakat.

Seharusnya masyarakat muslim di Indonesia menjadi salah satu yang terpenting dan menjadi pemenang saat perencanaan gerakan sadar zakat, mengingat banyaknya masyarakat muslim yang ada di Indonesia. Berdasarkan perhitungan BAZNAS, Indonesia memiliki potensi zakat sebesar Rp. Tetapi dengan demikian, apakah mungkin faktor pengetahuan zakat, pendapatan dan sikap berpengaruh terhadap peningkatan penerimaan zakat tersebut. Dengan demikian pendapatan akan berpengaruh signifikan terhadap minat seseorang untuk membayar zakat, ataupun sebaliknya pendapatan tidak berpengaruh signifikan terhadap minat membayar zakat.

Begitu juga dengan sikap seseorang terhadap minat membayar zakat. Jika sikap seseorang terhadap zakat sudah tidak peduli atau acuh maka bisa jadi mempengaruhi seseorang untuk enggan membayar zakat sesuai kewajibannya. Salah satu faktor yang menjadikan suatu daerah mengalami keberhasilan dalam pengumpulan zakat adalah adanya faktor keagamaan. Keagamaan sangat berpengaruh karena seseorang yang beragama 
akan menunaikan sema kewajiban dalam beribadahnya, salah satunya adalah zakat.

Karena zakat merupakan salah satu kewajiban yang diajarkan dalam agama islam selain sholat yang wajib di tunaikan. Jadi tingkat religiositas berpengaruh terhadap pengetahuan zakat dan minat membayar zakat. Karena tingkat religiuitas apabila seseorang memiliki tingkat religiuitas tinggi, otomatis seseorang tersebut mengetahui tentang pengetahuan zakat dan memiliki Minat Membayar Zakat yang tinggi. Agama Islam telah menyatakan dengan tegas, bahwa setiap muslim wajib menunaikan zakatnya, apabila hartanya telah memenuhi kriteria dan syarat tertentu, karena zakat merupakan salah satu rukun dan fardhu dalam kita melaksanakan ibadah kepada Allah SWT.

Namun belum tentu seseorang yang memiliki tingkat religioitas tidak mengetahui tentang zakat. Dengan itu penelitian ini dibuat untuk membuktikan kepastian bahwa faktor religiositas, pendapatan dan sikap apakah berpengaruh terhadap peningkatan penerimaan zakat tersebut atau tidak dan apakah pengetahuan dapat memoderasi faktor religiositas, pendapatan dan sikap masyarakat muslim kabupaten semarang dapat berpengaruh terhadap peningkatan penerimaan zakat tersebut atau tidak.

\section{Kajian Teori}

\section{Zakat}

Istilah zakat dapat dikatakan dengan istilah (masdar) karena zaka yang berarti berkah, tumbuh, bersih dan baik. Menurut Ibn Manzur pada Lisan al"Arab, bahwa istilah zakat dilihat atau di cermati menurut sudut bahasa bermakna tumbuh, berkat dan terpuji yang mana seluruh perkataan ini digunakan di dalam Al-Quran dan Al-Hadist. Menurut bahasa zakat sering dikatakan sebagai tumbuh dan berkembang, atau menyucikan karena zakat akan mengembangkan dan memperbanyak pahala seseorang yang melaksanakannya serta membersihkannya dari segala dosa. Menurut syariat, zakat ialah hak wajib dari harta tertentu dalam waktu tertentu. Sedangkan zakat menurut istilah, definisi zakat dalam kajian fikih sering dikatakan, sebagaimana ditulis oleh beberapa fuqoha' (pakar fikih), tercatat beberapa redaksi yang memiliki maksud yang relatif sama. 
Juli-Desember 2021: 169 - 188

Di antara berbagai pengertian - pengertian yang telah dikemukakan oleh para fuqoha' atau ahli fikih yaitu: Asy-Syaukani mengatakan bahwa, zakat ialah suatu anugerah atau dapat diartikan sebagai pemberian sebagian dari harta yang sudah mencapai nishab kepada orang fakir, miskin dan sebagainya yang berhubungan dengan itu, serta tidak mempunyai sifat yang dapat dicegah syara' untuk seseorang guna tasharuf kepadanya. Menurut Sayyid Sabiq, zakat yaitu sesuatu sebutan dari suatu hak yang akan diberikan Allah SWT yang dapat dikeluarkan seseorang untuk fakir, miskin, dan golongannya. Zakat itu sendiri dinamakan sebagai zakat, karena dengan mengeluarkan zakat atau menunaikan zakat di dalamnya terkandung suatu harapan untuk memperoleh berkah serta pahala dari Allah SWT, pembersihan jiwa seseorang dari sifat kikir untuk golongan orang kaya atau menghilangkan rasa iri hati dari golongan orang-orang miskin dan memupuknya dengan berbagai kebajikan ${ }^{3}$.

\section{Religiositas}

Ada berbagai istilah untuk dapat mengistilahkan agama, antara lain religi, religion dalam bahasa Inggris, religie dalam bahasa Belanda, religio atau relegare dalam bahasa Latin, dan yang terakhir dien dalam bahasa Arab. Kata religion dalam bahasa Inggris dan religie dalam bahasa Belanda ialah berasal dari bahasa induk dari kedua bahasa tersebut, yaitu bahasa Latin "religio" dari akar kata "relegare" yang berarti mengikat. Menurut Cicero dalam Ismail (1997), relegare dapat diartikan sebagai melakukan sesuatu perbuatan dengan penuh penderitaan, yaitu dapat digolongkan dalam jenis laku peribadatan yang dikerjakan berulangulang dan tetap seperti itu. Dalam bahasa Arab, agama dikenal dengan kata al-din dan al-milah. Kata al-din sendiri mengandung bermacam- macam arti. Ia bisa berarti al-mulk (kerajaan), al-khidmat (pelayanan), al-izz (kejayaan), al-dzull (kehinaan), al-ikrah (pemaksaan), al-ihsan (kebajikan), al-adat (kebiasaan), alibadat (pengabdian), al-qahr wa al-sulthan (kekuasaan dan pemerintahan), altadzallul wa al-khudu (tunduk dan patuh), al-tha'at (taat), al-islam al-tauhid (penyerahan dan mengesakan Tuhan) ${ }^{4}$.

Religiositas sering disamaartikan dan disangkutpautkan dengan Agama. Dari suatu istilah agama inilah kemudian dapat muncul arti yang menyatakan apa yang dinamakan religiositas. Meski berakar kata sama, namun dalam 
penggunaannya istilah religiositas mempunyai makna yang berbeda dengan religi atau agama. Religiositas memiliki lima dimensi di antaranya yaitu dimensi keyakinan (ideologis), dimensi peribadatan atau praktik agama (ritualitas), dimensi pengalaman, dimensi pengetahuan agama, dimensi pengalaman dan konsekuensi ${ }^{5}$.

\section{Pendapatan}

Pendapatan merupakan salah satu kompensasi yang didapatkan atau diperoleh seorang guna melalui berbagai aktivitas pekerjaan yang akan sesuai dengan syariah oleh seorang dalam upaya memenuhi kebutuhan hidup. Akan tetapi setiap kekayaan yang akan diperoleh seseorang tersebut harus diketahui asal usul dari mana sumbernya dan bersifat tetap atau tidak ${ }^{6}$. Ajaran Islam ini telah mewajibkan setiap harta atau kekayaan yang telah didapatkan oleh seseorang wajib hukumnya untuk dizakatkan. Adapun beberapa contoh yang dapat dilihat dari kewajiban zakat adalah antara lain pendapatan dari hasil pertanian, dari hasil barang tambang, serta pendapatan dari hasil pekerjaan lainnya, seperti gaji/upah, honorarium dan hasil-hasil lain yang didapatkan dari berbagai pekerjaan yang halal dan dari hasil perdagangan.

Upaya dalam suatu usaha guna memaksimalkan setiap keuntungan atau profit atau keuntungan berarti pula meningkatkan producer surplus, serta memiliki upaya guna meningkatkan suatu pembayaran zakat $\left({ }^{7}\right.$. Jadi dengan demikian adanya pengenaan zakat perniagaan perilaku memaksimalkan profit berjalan sejalan dengan perilaku memaksimalkan zakat. Variabel pendapatan/penghasilan dapat berpengaruh secara signifikan terhadap keinginan masyarakat untuk menunaikan zakat di lembaga zakat $\left({ }^{8}\right.$.

Semua jenis pendapatan akan dipergunakan oleh sektor rumah tangga untuk dua tujuan. Pertama untuk membelikan barang atau jasa yang diperlukan oleh sektor rumah tangga. Yang kedua selain di belanjakan pendapatan yang didapat sektor rumah tangga akan disimpan atau di tabung untuk pemenuhan kebutuhan lain - lain $\left({ }^{9}\right.$. Pendapatan memiliki beberapa unsur yang menjelaskan tentang bagaimana pendapatan itu diperoleh, berikut unsur - unsurnya: Pendapatan yang diperoleh dari hasil produksi barang ataupun jasa, Imbalan yang didapat setelah penggunaan aktiva pada sumber - sumber ekonomi suatu 
Juli-Desember 2021: 169 - 188

perusahaan oleh pihak lain, Dari penjualan aktiva di luar barang - barang dagangan adalah unsur pendapatan lain - lain dari suatu perusahaan ${ }^{10}$.

Pendapatan terdiri dari dua jenis yakni pendapatan operasi dan pendapatan non oprasi. Pendapatan memiliki tiga indikator yaitu gaji, tunjangan, tenghasilan lainlain

\section{Sikap}

Sikap adalah suatu julukan atau istilah yang ada pada bidang psikologi yang memiliki hubungan dengan persepsi atau tanggapan seseorang dan tingkah laku seseorang yang dimilikinya. Menurut Kamus Besar Bahasa Indonesia (KBBI) sikap yaitu perbuatan atau perilaku seseorang yang didasari oleh keyakinan berdasarkan norma - norma yang sudah ada dalam masyarakat dan biasanya juga menyangkut norma agama. Sikap dalam beberapa hal merupakan suatu penentu yang paling penting untuk seseorang dalam tingkah lakunya. Sikap bisa digolongkan juga menjadi reaksi, dengan demikian sikap selalu berhubungan dengan dua reaksi yaitu senang dan tidak senang. Dua raksi tersebut menggambarkan bahwa seseorang akan melakukan sesuatu atau menjauhinya.

Sikap seseorang individu sangat erat kaitannya dengan perilaku manusia. Sikap seseorang memang harus konsisten dengan perilaku yang dimilikinya ${ }^{11}$. Namun seandainya sikap seseorang tersebut tidak konsisten dengan perilaku mungkin ada faktor yang mempengaruhi dari luar diri seseorang yang membuat sikap dan perilaku tidak seimbang. Faktor tersebut merupakan seperti norma, politik, budaya, dan lain sebagainya yang berkaitan dengan sistem nilai eksternal yang ada dalam masyarakat. Sikap memiliki beberapa model yang sangat penting yaitu model sikap tiga komponen (three component model), model sifat multi sifat, model sikap terhadap iklan.

Di setiap model tersebut memiliki perspektif yang berbeda - beda mengenai jumlah bagian - bagian komponen suatu sikap dan bagaimana suatu komponen ini disusun atau saling berhubungan Sikap juga memiliki beberapa karakteristik sebagai berikut ${ }^{12}$ sikap memiliki objek, konsistensi sikap, sikap positif, negatif, dan netral, intensitas sikap. 
Sikap memiliki beberapa teori diantaranya teori sikap beralasan, teori sikap mencoba, dan teori perilaku terancam. Teori tersebut menjelaskan bahwa sikap dapat dipengaruhi oleh situasi dan objeknya ${ }^{13}$.

Menurut Sax dalam Peinciples of Educational and Psychological Measurement and Evaluation bahwa sikap tersebut mempunyai beberapa dimensi yaitu diantaranya adalah arah, intensitas, keluasan, konsistensi, dan spontanitas. Berikut pemaparan tentang dimensi sikap yaitu arah, intensitas , keluasan, konsistensi, spontanitas $\left({ }^{14}\right.$.

\section{Minat membayar zakat}

Dilihat dari Faktor suatu pengetahuan tentang islam ini dapat berhubungan dengan suatu kewajiban yang harus ditunaikan oleh seseorang dalam melaksanakan hukum - hukum syariat yang sudah ada yang harus dianut oleh seseorang tersebut seperti halnya menunaikan zakat yang harus ditunaikan atas penghasilan yang telah didapatnya. Namun kendala yang sering berkembang dalam arus pertanggungjawaban zakat adalah skeptisisme masyarakat terhadap lembaga pengelola zakat. Masyarakat akan menganggap lembaga tersebut tidak dapat dipercaya dan tidak bertanggung jawab dalam upayanya menerima, mengelola, dan mendistribusikan zakat, sehingga menimbulkan ketidakpercayaan.

Dalam rangka meningkatkan kepercayaan masyarakat terhadap lembaga, lembaga harus memberikan bentuk pertanggungjawaban atas setiap tindakan dan upaya lembaga yang didokumentasikan dalam bentuk pelaporan keuangan guna memenuhi semua tujuan organisasi untuk periode tertentu. Masalah lain yang membuat individu ragu untuk membelanjakan sebagian kecil dari pendapatannya atau membayar zakat adalah berbagai jenis layanan yang diberikan oleh organisasi ini tidak sesuai dengan kebutuhan konsumen, dan muzaki tidak mendapat reaksi positif dari institusi tersebut.

Minat memiliki tiga faktor yang mempengaruhi minat itu sendiri yaitu pengetahuan, informasi, dan pengalaman ketiga faktor tersebut yang mempengaruhi minat seseorang untuk merespon suatu objek. Sedangkan menurut teori dari Lestar D. Crow dan Alice dalam ${ }^{15}$ membahas tentang adanya tiga indikator dalam minat yaitu yang pertama dorongan dari dalam diri sendiri atau bisa di sebut reflek seseorang yang di munculkan dari diri sendiri (individu), yang kedua dorongan dari luar diri sendiri atau reflek yang disebabkan karena motif 
sosial atau bisa disebut dorongan dari luar diri, yang ketiga adalah faktor emosi atau suatu reflek yang di sebabkan oleh emosional diri sendiri.

\section{Pengetahuan}

Pengetahuan sering dihubungkan dengan dimana keadaan ketika subjek memahami objek. Pengetahuan merupakan hasil tau manusia tentang kerjasama manusia dengan subjek yang mengetahui dan objek yang diketahui ${ }^{16}$. Pengetahuan memiliki tiga jenis yaitu:

a. Pengetahuan rasional atau bisa diartikan sebagai pengetahuan yang didapat melalui penalaran rasional

b. Pengetahuan intuitif atau bisa diartikan sebagai pengetahuan yang didapat melalui pesan secara individu.

c. Pengetahuan empiris atau bisa diartikan sebagai pengetahuan yang didapat melalui pengalaman konkrit.

Menurut Anderson \& Krathwohl dikatakan bahwa dimensi pengetahuan adalah sebagai berikut $\left({ }^{17}\right.$ :

1. Pengetahuan Faktual

2. Pengetahuan Konseptual

3. Pengetahuan Prosedural

4. Pengetahuan Metakognitif

Pengetahuan secara prinsip dapat dibedakan menjadi beberapa tahapan. Tahapan yang pertama adalah penalaran, selanjutnya logika, dan sumber pengetahuan itu sendiri. Berikut klasifikasi dasar pengetahuan ${ }^{18}$ :

a) Penalaran

b) Hakikat penalaran

c) Logika

d) Sumber pengetahuan

Pengetahuan memiliki dua jenis yakni yang pertama pengetahuan umum yang berhubungan dengan lingkungan dan perilaku yang dimunculkan oleh mereka, yang kedua yaitu pengetahuan prosedural yang mengenai cara melakukan sesuatu. 
a. Pengetahuan umum atau dapat disebut dengan general knowledge menyatakan bahwa interpretasi seseorang individu atas informasi yang benar atau relevan dalam suatu lingkungan.

b. Pengetahuan procedural (procedural knowledge) menyatakan bahwa pengetahuan tentang cara melakukan sesuatu. Pengetahuan prosedural ini juga tersimpan dalam memori sebagai salah satu jenis hubungan ${ }^{19}$.

Jadi dapat disimpulkan bahwa pengetahuan merupakan sesuatu yang telah diketahui, dipahami, dan dimengerti oleh seseorang. Pengetahuan juga dapat diartikan sebagai suatu gejala yang diperoleh dan ditemukan oleh manusia melalui pengamatan akal yang sudah dilakukannya. Pada saat seorang manusia dengan menggunakan akalnya untuk mengenali sesuatu objek atau kejadian yang belum pernah dirasakan atau dialami sebelumnya maka tindakan tersebut dapat memunculkan sebuah pengetahuan, pada hakikatnya pengetahuan memiliki kemampuan untuk memperkirakan sesuatu sebagai hasil pengenalan suatu pola atau bentuk. Terkadang data atau informasi dapat membuat seseorang menjadi bingung, namun dengan pengetahuan terkadang dapat mengarahkan seseorang untuk melakukan tindakan yang akan dilakukannya.

\section{Kerangka Berfikir}

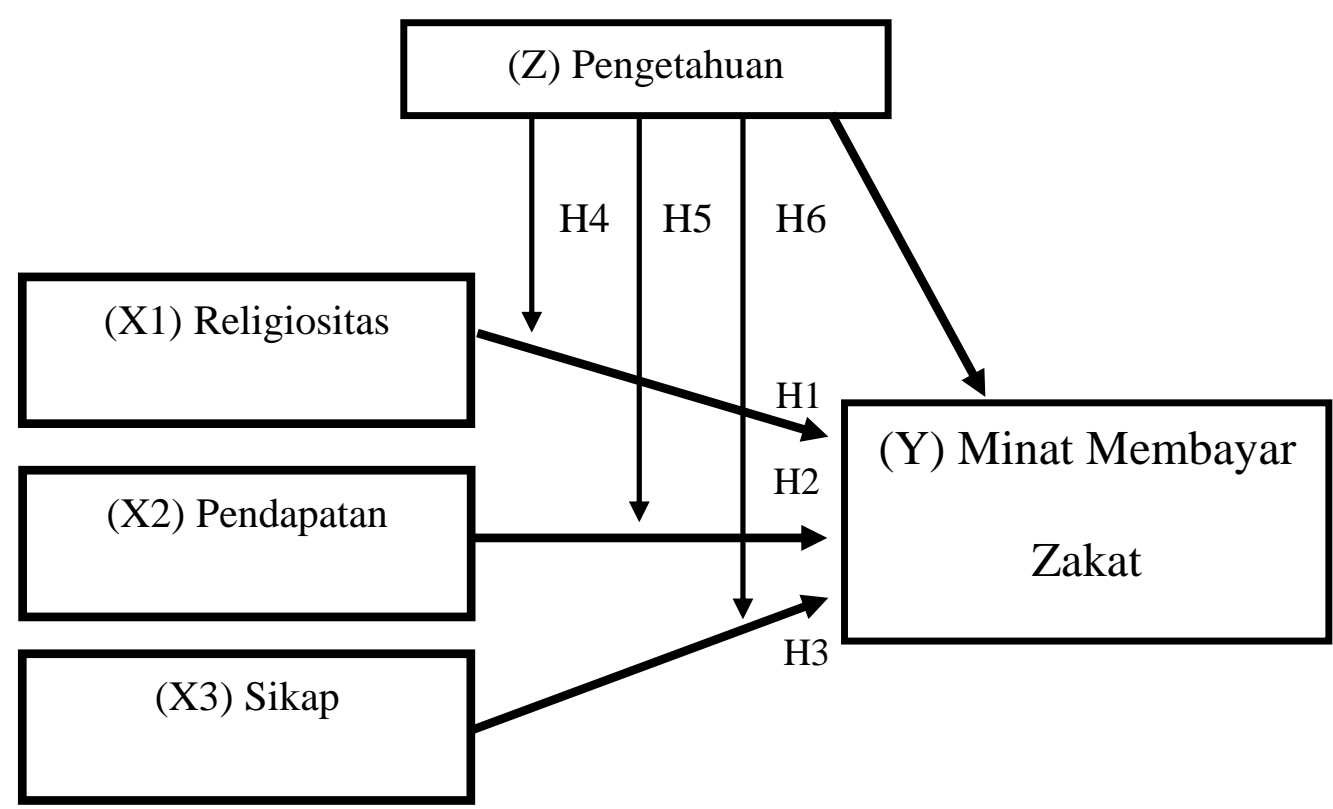


Juli-Desember 2021: 169 - 188

\section{Metode Penelitian}

Penelitian ini merupakan penelitian yang termasuk dalam penelitian kuantitatif yang termasuk dalam golongan penelitian lapangan (field research). Pendekatan kuantitatif sering disebut sebagai pendekatan ilmiah terhadap pengambilan keputusan manajerial dan ekonomi. Metode kuantitatif ini disebut sebagai metode positif karena berlandaskan kepada filsafat positivism. Metode kuantitatif sering di sebut juga sebagai metode tradisional, karena metode ini sudah sangat cukup lama digunakan untuk metode penelitian sehingga sudah sangat mentradisi sebagai metode penelitian.

Metode kuantitatif juga sebagai metode ilmiah atau scientific karena telah memiliki kaidah - kaidah ilmiah yaitu konkrit/empiris, obyektif, terukur, rasional, dan sistematis. Metode ini juga dapat dikatakan sebagai metode discovery, karena dengan metode ini dapat menghasilkan penelitian yang dapat dikembangkan menjadi berbagai iptek baru. Pendekatan yang digunakan ini berawal dari data yang bersifat angka dan analisis menggunakan statistik ${ }^{20}$. Dari pengumpulan data dari penyebaran kuesioner kepada 100 responden.

\section{Hasil Penelitian}

a) Uji t

Uji statistik $\mathrm{t}$ berfungsi untuk menunjukkan seberapa besar pengaruh satu variabel bebas secara individual dalam menjelaskan variasi terikat. Dalam mengambil keputusan uji ini menggunakan cara melihat nilai koefisien mempunyai nilai positif dan signifikansi kurang dari 0.05 maka dapat diketahui bahwa variabel bebas berpengaruh terhadap variable terikat ${ }^{21}$. Berikut tabel dari hasil uji t pada dapa yang telah di olah dengan aplikasi IMB SPSS 25 sesuai dengan jawaban yang di berikan responden dalam kuesioner. Dapat dilihat dari tabel 4.11 dibawah ini apakah masing - masing variabel pengetahuan (X1), variabel pendapatan (X2), dan variabel sikap (X3), memiliki pengaruh terhadap variabel minat membayar zakat (Y) atau tidak. 
Table 4.11 Hasil Uji t Terhadap Variabel Y

Coefficients $^{\mathrm{a}}$

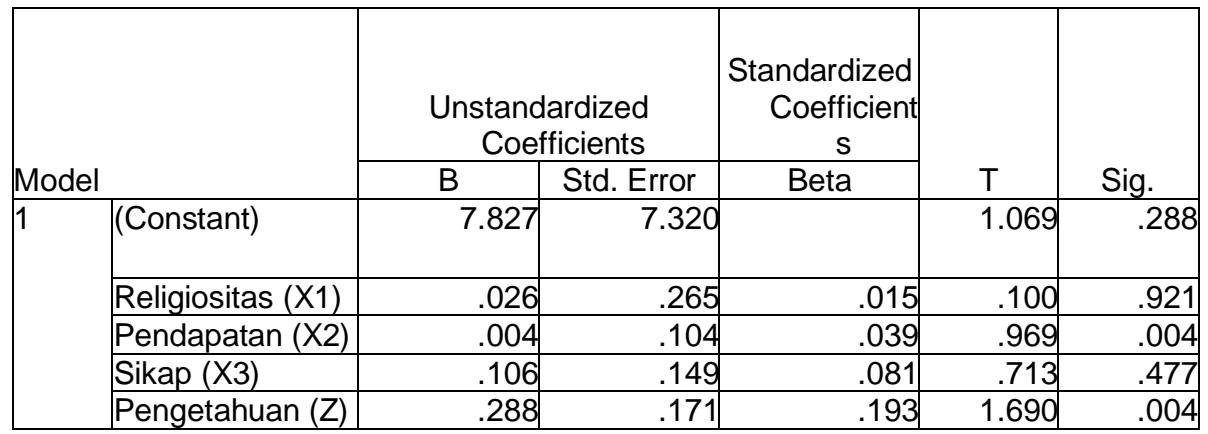

a. Dependent Variable: Minat Membayar Zakat $(\mathrm{Y})$

Sumber : Data Primer diolah 2021

Berikut hasil kesimpulan dari uji t pada tabel 4.11 diatas:

a) Variabel religiositas (X1) memiliki nilai signifikan sebesar 0,921 yang berarti lebih besar dari 0,05. Dengan demikian dapat disimpulkan bahwa tidak ada pengaruh antara sikap (X1) terhadap minat membayar zakat (Y).

b) Variabel pendapatan (X2) memiliki nilai signifikan sebesar 0,004 yang berarti lebih besar dari 0,05. Dengan demikian dapat disimpulkan bahwa terdapat pengaruh positif dan signifikan pengaruh antara pendapatan (X2) terhadap minat membayar zakat (Y).

c) Variabel sikap (X3) memiliki nilai signifikan sebesar 0,477 yang berarti lebih besar dari 0,05. Dengan demikian dapat disimpulkan bahwa tidak ada pengaruh antara sikap (X3) terhadap minat membayar zakat (Y).

d) Variabel pengetahuan (Z) memiliki nilai signifikan sebesar 0,004 yang berarti lebih kecil dari 0,05. Dengan demikian dapat disimpulkan bahwa terdapat pengaruh positif dan signifikan antara pengetahuan $(Z)$ terhadap minat membayar zakat (Y).

b) Uji F

Uji F berguna untuk mengetahui apakah semua variabel independen secara serentak memiliki pengaruh terhadap variabel dependen. Uji ini dilakukan menggunakan ANOVA (Analysis of Variance) dengan melihat nilai signifikansinya. Jika nilai signifikan lebih besar dari 0,05 maka dapat disimpulkan bahwa variabel independen tidak berpengaruh terhadap variabel 
dependen. Begitu juga sebaliknya jika nilai signifikan kurang dari 0,05 maka variabel independen berpengaruh terhadap variabel dependen ${ }^{22}$. berikut hasil uji F dari variabel $\mathrm{X}$ dan $\mathrm{Z}$ terhadap $\mathrm{Y}$.

Table 4.12 Hasil Uji $F$

ANOVA $^{\mathrm{a}}$

\begin{tabular}{|l|l|r|r|r|r|c|}
\hline \multicolumn{2}{|l|}{ Model } & $\begin{array}{r}\text { Sum of } \\
\text { Squares }\end{array}$ & Df & $\begin{array}{r}\text { Mean } \\
\text { Square }\end{array}$ & F & Sig. \\
\hline 1 & Regression & 516.935 & 3 & 172.312 & 42.037 & $.000^{\circ}$ \\
\cline { 2 - 7 } & Residual & 393.505 & 96 & 4.099 & & \\
\cline { 2 - 8 } & Total & 910.440 & 99 & & & \\
\hline
\end{tabular}

a. Dependent Variable: Minat Membayar Zakat (Y)

b. Predictors: (Constant), Pengetahuan (Z), Pendapatan (X2), Sikap (X3), Religiositas (X1)

Sumber : Data Primer diolah 2021

Berdasarkan table 4.12 tersebut dapat diketahui nilai signifikan adalah sebesar 0,000 yang berarti kurang dari 0,05. Dengan demikian dapat disimpulkan bahwa secara bersama-sama variable religiositas, pendapatan, sikap, dan pengetahuan berpengaruh terhadap variable minat membayar zakat.

c) $\mathrm{Uji}^{2}$

Uji koefisien determinasi atau $\mathrm{R}^{2}$ menurut ${ }^{23}$ yaitu uji yang digunakan untuk mengetahui sejauh mana ketepatan garis regresi atau model regresi yang terbentuk dalam mewakili kelompok hasil data pengamatan. Jadi uji koefisien determinasi digunakan untuk melihat sejauh mana kontribusi pengaruh variabel independen terhadap variabel dependen. Besar nilai koefisien determinasi adalah antara 0 dan 1 . Semakin nilai $\mathrm{R}^{2}$ mendekati 1 , maka ketepatan dikatakan semakin baik.

Table 4.13 Hasil Uji R²

Model Summary

\begin{tabular}{|c|c|c|c|c|}
\hline Model & $\mathrm{R}$ & R Square & $\begin{array}{r}\text { Adjusted R } \\
\text { Square } \\
\end{array}$ & $\begin{array}{c}\text { Std. Error of the } \\
\text { Estimate }\end{array}$ \\
\hline 1 & $.741^{a}$ & .714 & .841 & 3.701 \\
\hline
\end{tabular}


Nio Okta Nugraheni: Analisis Pengaruh Religiositas... $\mid 180$

a. Dependent Variable: Minat Membayar Zakat

Sumber : Data Primer diolah 2021

Berdasarkan tabel 4.13 menunjukan hasil uji koefisien determinasi $\left(\mathrm{R}^{2}\right)$ dengan keterangan sebagai berikut:

1) Nilai koefisien korelasi (R) adalah sebesar 0,741 maka dapat disimpulkan bahwa nilai $\mathrm{R}$ mendekati nilai angka 1. Sehingga dapat disimpulkan terdapat hubungan yang kuat antar variable independen dengan variabel dependen.

2) Nilai koefisien determinasi $\left(\mathrm{R}^{2}\right)$ adalah sebesar 0,714 yang dapat diartikan bahwa variabel independen memberikan kontribusi pengaruh terhadap variabel dependen sebesar 71,4\% sedangkan 28,6\% dipengaruhi oleh variabel lain yang tidak termasuk dalam penelitian ini.

\section{Uji Moderated Regression Analysis (MRA)}

Uji moderasi yang digunakan adalah Moderated Regression Analysis (MRA). Uji MRA ini berbeda dengan analisis sub kelompok karena menggunakan pendekatan analitik yang mempertahankan integritas sampel dan memberikan data untuk mengontrol pengaruh variabel moderator. Untuk menggunakan MRA dengan satu variabel predictor $(\mathrm{X})$, maka dengan itu harus membandingkan dua persamaan regresi untuk menentukan jenis variabel moderator $^{24}$.

Rumus persamaan MRA sebagai berikut:

$\mathrm{Y}=\mathrm{a}+\mathrm{b} 1 \mathrm{X}+\mathrm{e}$

$\mathrm{Y}=\mathrm{a}+\mathrm{b} 1 \mathrm{X}+\mathrm{b} 2 \mathrm{Z}+\mathrm{e}$

$\mathrm{Y}=\mathrm{a}+\mathrm{b} 1 \mathrm{X}+\mathrm{b} 2 \mathrm{Z}+\mathrm{b} 3 \mathrm{X} 1 * \mathrm{Z}+\mathrm{e}$

Dapat dilihat dibawah ini hasil hubungan moderasi dalam penelitian ini ialah terkait dengan:

Table 4.14 Hasil Uji MRA

\section{Coefficientsa}

\begin{tabular}{|c|c|c|c|c|c|c|}
\hline \multirow[b]{2}{*}{ Model } & & \multicolumn{2}{|c|}{$\begin{array}{r}\text { Unstandardized } \\
\text { Coefficients }\end{array}$} & \multirow{2}{*}{ 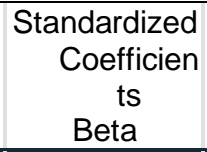 } & \multirow[b]{2}{*}{$\mathrm{T}$} & \multirow[b]{2}{*}{ Sig. } \\
\hline & & B & Std. Error & & & \\
\hline 1 & (Constant) & 49.602 & 33.340 & & 1.488 & .140 \\
\hline & $\begin{array}{l}\text { Religiositas } \\
\text { (X1) }\end{array}$ & 1.481 & .604 & 1.478 & 2.452 & .016 \\
\hline
\end{tabular}


Juli-Desember 2021: 169 - 188

\begin{tabular}{lrrrrr}
\hline $\begin{array}{c}\text { Pendapatan } \\
(\mathrm{X} 2)\end{array}$ & 2.405 & 1.070 & 1.305 & 2.248 & .027 \\
\hline Sikap (X3) & .306 & .873 & .252 & .350 & .727 \\
\hline $\begin{array}{c}\text { Pengetahuan } \\
(\mathrm{Z})\end{array}$ & .375 & 1.491 & .241 & .252 & .802 \\
\hline ModerasiU1 & .089 & .027 & 2.729 & 3.278 & .001 \\
\hline ModerasiU2 & .096 & .045 & 2.196 & 2.133 & .006 \\
\hline ModerasiU3 & .669 & .039 & .382 & .429 & .017 \\
\hline
\end{tabular}

a. Dependent Variable: Minat Membayar Zakat

Sumber : Data Primer diolah 2021

a) Pengaruh religiositas terhadap minat membayar zakat oleh pengetahuan. Berikut hasil uji Moderated Regression Analysis (MRA):

Hasil uji t pada tabel di atas menunjukkan variabel religiositas (X1) memiliki nilai signifikan sebesar 0,016 yang berarti lebih kecil dari 0,05, dan tingkat Religiositas (X1) memberikan nilai koefisien sebesar 1,481. Data pada tabel 4.14 di atas yang memiliki keterangan moderasi 1 merupakan hasil data yang sudah dimasukan variabel moderasi dengan hasil yang menunjukkan variabel Religiositas (X1) memberikan nilai koefisien sebesar 0,089 dengan tingkat signifikansi 0,01. Dengan demikian ternyata variabel moderasi pengetahuan menunjukkan hasil yang signifikan karena nilai signifikansinya lebih kecil dari 0,05 , dan nilai koefisien pada hasil tersebut positif dengan nilai koefisien 0,089. Dengan demikian dapat disimpulkan variabel moderasi pada uji moderasi 1 yang merupakan interaksi dari pengetahuan $(Z)$ mempengaruhi variabel religiositas (X1) terhadap minat masyarakat muslim Kabupaten Semarang, serta dapat dikatakan variabel moderasi memperlemah.

b) Pengaruh pendapatan terhadap minat membayar zakat oleh pengetahuan. Berikut hasil uji Moderated Regression Analysis (MRA):

Hasil uji t pada tabel 4.14 menunjukkan variabel pendapatan (X2) memiliki nilai signifikan sebesar 0,016 yang berarti lebih kecil dari 0,05, dan nilai koefisien pendapatan (X2) yaitu sebesar 2,405. Pada data tabel 4.14 di atas yang memiliki keterangan moderasi 2 merupakan hasil data yang sudah dimasukan variabel moderasi dengan hasil yang menunjukkan variabel pendapatan (X2) memberikan nilai koefisien sebesar 0,096 dengan tingkat signifikansi 0,006. Dengan demikian ternyata variabel moderasi pengetahuan menunjukkan hasil yang signifikan karena nilai signifikansinya lebih kecil dari 0,05, dan nilai koefisien pada hasil tersebut positif dengan nilai koefisien 0,096 
dengan demikian dapat disimpulkan variabel pengetahuan (Z) merupakan variabel moderasi.

c) Pengaruh sikap terhadap minat membayar zakat oleh pengetahuan. Berikut hasil uji Moderated Regression Analysis (MRA):

Hasil uji t pada tabel 4.14 menunjukkan variabel sikap (X3) memiliki nilai signifikan sebesar 0,727 yang berarti lebih besar dari 0,05, dan nilai koefisien sikap (X3) yaitu sebesar 0,306. Data pada tabel 4.14 di atas yang menunjukan keterangan moderasi 3 merupakan hasil data yang sudah dimasukan variabel moderasi dengan hasil yang menunjukkan variabel sikap (X3) memberikan nilai koefisien sebesar 0,669 dengan tingkat signifikansi 0,017, Dan nilai koefisien pada hasil tersebut positif dengan nilai koefisien 0,669. Dengan demikian dapat disimpulkan moderasi 3 yang merupakan interaksi dari pengetahuan (Z) mempengaruhi variabel sikap (X3) terhadap minat masyarakat muslim Kabupaten Semarang, serta dapat dikatakan variabel moderasi memperlemah.

Pembahasan Hasil

1. Religiositas mempengaruhi minat masyarakat Kabupaten Semarang untuk membayar zakat.

Hasil pengujian yang dilakukan dalam penelitian ini menghasilkan variabel pengetahuan dengan minat membayar zakat memiliki pengaruh positif dan signifikan, karena dapat dilihat dari tabel t hitung variabel pengetahuan (X1) memiliki nilai t hitung sebesar 1.690, serta nilai signifikan sebesar 0,004 yang berarti lebih kecil dari 0,05 dan memiliki nilai koefisien parameter sebesar 0,193. Dengan demikian dapat disimpulkan bahwa terdapat pengaruh positif dan signifikan antara pengetahuan (X1) terhadap minat membayar zakat (Y).

2. Pendapatan mempengaruhi minat masyarakat Kabupaten Semarang untuk membayar zakat.

Hasil pengujian yang dilakukan dalam penelitian ini menghasilkan variabel pendapatan dengan minat membayar zakat memiliki pengaruh positif dan signifikan, karena dapat dilihat dari tabel t hitung variabel pendapatan (X2) memiliki nilai t hitung sebesar 0.969 , serta nilai signifikan sebesar 0,004 yang berarti lebih besar dari 0,05, dan memiliki nilai koefisien parameter sebesar 
0,039. Dengan demikian dapat disimpulkan bahwa terdapat pengaruh positif dan signifikan pengaruh antara pendapatan (X2) terhadap minat membayar zakat (Y).

3. Sikap mempengaruhi minat masyarakat Kabupaten Semarang untuk membayar zakat.

Hasil pengujian yang dilakukan dalam penelitian ini menghasilkan variabel sikap dengan minat membayar zakat tidak memiliki pengaruh, karena variabel sikap (X3) memiliki nilai t hitung sebesar 0,713, serta memiliki nilai signifikan sebesar 0,477 yang berarti lebih besar dari 0,05, dan memiliki nilai koefisien parameter sebesar 0,039. Dengan demikian dapat disimpulkan bahwa tidak ada pengaruh antara sikap (X3) terhadap minat membayar zakat (Y).

4. Pengetahuan memoderasi religiositas terhadap minat masyarakat Kabupaten Semarang untuk membayar zakat.

Hasil dari pengujian yang dilakukan dengan ditunjukkan melalui persamaan regresi dengan uji interaksi atau sering disebut dengan Moderated Regression Analysis (MRA) dalam penelitian ini menunjukkan bahwa variabel pengetahuan (Z) memperlemah variabel religiositas. Karena hasil uji t mengatakan variabel religiositas (X1) memberikan nilai koefisien sebesar 0,026 dengan tingkat signifikansi 0,921,dan variabel pengetahuan (Z) memberikan nilai koefisien sebesar 0,288 dengan tingkat signifikansi 0,004. Sedangkan variabel moderasi pengetahuan dengan X1 religiositas dalam uji MRA memberikan nilai koefisien sebesar 1,481 dengan tingkat signifikansi 0,016. Variabel moderasi religiositas (X1) pengetahuan menunjukkan hasil yang signifikan karena nilai signifikansinya lebih kecil dari 0,05. Dan nilai koefisien pada hasil tersebut positif dengan nilai koefisien 0,089 dengan demikian dapat disimpulkan moderasi berpengaruh.

5. Pengetahuan memoderasi pendapatan terhadap minat masyarakat Kabupaten Semarang untuk membayar zakat.

Hasil dari pengujian yang dilakukan dengan ditunjukkan melalui persamaan regresi dengan uji interaksi atau sering disebut dengan Moderated Regression Analysis (MRA) dalam penelitian ini menunjukkan bahwa variabel pengetahuan (Z) memperlemah variabel pendapatan (X2). Karena hasil dari uji 
t mengatakan bahwa variabel pendapatan (X2) memberikan nilai koefisien sebesar 0,004 dengan tingkat signifikansi 0,004, variabel pengetahuan (Z) memberikan nilai koefisien sebesar 0,288 dengan tingkat signifikansi 0,004, variabel moderasi religiositas dengan pendapatan X2 dalam uji MRA memberikan nilai koefisien 0,096 dengan tingkat signifikansi 0,006. Variabel moderasi pendapatan (X2) pengetahuan menunjukkan hasil yang signifikan karena nilai signifikansinya lebih besar dari 0,05. Dan nilai koefisien pada hasil tersebut positif dengan nilai koefisien 0,096 dengan demikian dapat disimpulkan moderasik berpengaruh.

6. Pengetahuan memoderasi sikap terhadap minat masyarakat Kabupaten Semarang untuk membayar zakat.

Hasil dari pengujian yang dilakukan dengan ditunjukkan melalui persamaan regresi dengan uji interaksi atau sering disebut dengan Moderated Regression Analysis (MRA) dalam penelitian ini menunjukkan bahwa variabel pengetahuan $(Z)$ memoderasi variabel sikap terhadap minat membayar zakat masyarakat Kabupaten Semarang. Karena hasil dari uji t mengatakan bahwa variabel sikap (X3) memberikan nilai koefisien sebesar 0,106 dengan tingkat signifikansi 0,477 , variabel pengetahuan (Z) memberikan nilai koefisien sebesar 0,288 dengan tingkat signifikansi 0,004, variabel moderasi pengetahuan dengan sikap X3 memberikan nilai koefisien 0,669 dengan tingkat signifikansi 0,017. Variabel moderasi pengetahuan dengan sikap (X3) menunjukkan hasil yang signifikan karena nilai signifikansinya lebih kecil dari 0,05. Dan nilai koefisien pada hasil tersebut positif dengan nilai koefisien 0,669 dengan demikian dapat disimpulkan moderasi memperlemah.

\section{Kesimpulan}

Berdasarkan hasil penelitian pengaruh religiositas, pendapatan, sikap terhadap minat membayar zakat masyarakat Kabupaten Semarang dengan pengetahuan sebagai variabel moderating yang sudah menghasilkan pengujian analisis data, pengujian hipotesis, dan pembahasan yang sudah dilakukan dan dituangkan dalam pembahasan dan hasil, maka dapat diambil kesimpulan sebagai berikut: 
Juli-Desember 2021: 169 - 188

a. Religiositas (X1) tidak berpengaruh terhadap minat masyarakat muslim Kabupaten Semarang untuk membayar zakat.

b. Pendapatan (X2) berpengaruh positif dan signifikan terhadap minat masyarakat muslim Kabupaten Semarang untuk membayar zakat.

c. Sikap (X3) tidak berpengaruh terhadap minat masyarakat muslim Kabupaten Semarang untuk membayar zakat.

d. Religiositas dapat dimoderasi oleh pengetahuan (X1xZ) pengetahuan memperlemah religiositas terhadap minat membayar zakat masyarakat muslim Kabupaten Semarang.

e. Pendapatan dapat dimoderasi oleh pengetahuan (X2xZ) pengetahuan memperlemah pendapatan terhadap minat membayar zakat masyarakat muslim Kabupaten Semarang.

f. Sikap dapat dimoderasi oleh pengetahuan (X3xZ) pengetahuan memperlemah sikap terhadap minat membayar zakat masyarakat muslim Kabupaten Semarang.

\section{Endnote}

${ }^{1}$ Zul Fahmi and Mukhlish M.Nur, "Pengaruh Pengetahuan, Pendapatan, Dan Kepercayaan, Terhadap Minat Muzakki Dalam Membayar Zakat Di Baitul Mal Kota Lhokseumawe," Jurnal Ekonomi Regional Unimal 1, no. 3 (2018): 19-29.

${ }^{2}$ Ahmad (STAIN KUDUS) Syafiq, "Zakat Ibadah Sosial Untuk Meningkatkan Ketaqwaan Dan Kesejahteraan Sosial," Ziswaf 2, no. 2 (2015): 380-400.

${ }^{3}$ Teuku Muhammad Hasby Ash-Shiddiqy, Pedoman Zakat (Semarang: PT. Pustaka Rizki Putra, 2009).

${ }^{4}$ Muhammad Fakhruddin, “Analisis Pengaruh Tingkat Pengetahuan Zakat,Tingkat Religius, Tingkat Pendapatan,Dan Tingkatkepercayaan Kepada Baznas Terhadap Minat Membayar Zakat Profesi Para Pekerja ( Studi Kasus Pekerja Di Dki Jakarta )," Skripsi (2016).

${ }^{5}$ Muhyidin, "Pengaruh Citra Perusahan, Pengetahuan Produk Bank, Kepercayaan, Dan Pelayanan Terhadap Minat Menjadi Nasabah Bank Syariah Dengan Religiusitas Sebagai Variabel Moderating," S Salatiga, no. Fakultas Ekonomi dan Bisnis Islam IAIN Salatiga (2017).

${ }^{6}$ Sumarwan, Ujang. Perilaku Konsumen (Teori Dan Penerapannya Dalam Pemasaran). Bogor: Penerbit Ghalia Indonesia, (2004: 204)

${ }^{7}$ Karim, Adiwarman A. EKONOMI MIKRO ISLAM. 5th Ed. Jakarta: Raja Grafindo Persada, 2015: 161)

${ }^{8}$ Satrio \& Siswantoro Eka, and Dodik Siswantoro. "Analisis Faktor Pendapatan, Kepercayaan Dan Religiusitas Dalam Mempengaruhi Minat Muzakki Untuk Membayar Zakat Penghasilan Melalui Lembaga Amil Zakat." Simposium Nasional Akuntansi XIX 1, no. 42016 : 308315)

${ }^{9}$ Sukirno, Sadono. MIKRO EKONOMI TEORI PENGANTAR. Tiga. jakarta: Rajagrafindo Persada, 2016: 36) 
${ }^{10}$ Dia Oktavia Sari, "Pengaruh Pemberian Pembiayaan Modal Kerja Terhadap Peningkatan Pendapatan Usaha Nasabah" (2017): 114.

${ }^{11}$ Yayat Suharyat, "HUBUNGAN ANTARA SIKAP, MINAT DAN PERILAKU MANUSIA," Jurnal region 1(3), 2009 1(3) (2009): Psikologi Komunikasi.

12 Ibid

13 ibid

14 ibid

${ }^{15}$ Djaali Pesikologi Pendidikan. Jakarta: Bumi Aksara, (2009)

${ }^{16}$ Yeremias Jena, FILSAFAT ILMU Kajian : Filosofis Atas Sejarah Dan Metodologi IImu Pengetahuan (Yogyakarta: Deepublish, 2015).

${ }^{17}$ Suwarto "Dimensi Pengetahuan Dan Dimensi Proses Kognitif." Widyatama 19, no. 1 2010: 76-91)

18 Jujun S. Suriasumantri, "FILSAFAT ILMU Studi Kasus: Telaah Buku Filsafat IImu (Sebuah Pengantar Populer) Oleh Jujun S. Suriasumantri," FILSAFAT ILMU Studi Kasus: Telaah Buku Filsafat Ilmu (Sebuah Pengantar Populer) oleh Jujun S. Suriasumantri (2017): 0-23.

${ }^{19}$ Muhyidin, "Pengaruh Citra Perusahan, Pengetahuan Produk Bank, Kepercayaan, Dan Pelayanan Terhadap Minat Menjadi Nasabah Bank Syariah Dengan Religiusitas Sebagai Variabel Moderating."

${ }^{20}$ Sugiono, Metode Penelitan Kuantitatif, Kualitatif Dan R\&D, Bandung: Alfabeta, 2016.

${ }^{21}$ Anton Bawono, Multivariate Analysis Dengan SPSS (STAIN Salatiga, 2006).

22 (Bawono, A., \& Shina, 2018)

${ }^{23}$ Bawono, A., \& Shina (2018)

${ }^{24}$ Imam Ghozali, Aplikasi Analisis Multiverat Dengan Program SPSS, Semarang: Badan Penerbit Universitas Diponegoro, 2013.

\section{Daftar Pustaka}

Azwar, S. Sikap Dan Perilaku Dalam: Sikap Manusia Teori Dan Pengkurannya. Yogyakarta: Pustaka Pelajar, 2016.

Bawono, A., \& Shina, A. F. I. Ekonomika Terapan Untuk Ekonomi Dan Bisnis Islam. LP2M IAIN Salatiga, 2018.

Bawono, Anton. Multivariate Analysis Dengan SPSS. STAIN Salatiga, 2006.

Djaali. Pesikologi Pendidikan. Jakarta: Bumi Aksara, 2009.

Fahmi, Zul, and Mukhlish M.Nur. "Pengaruh Pengetahuan, Pendapatan, Dan Kepercayaan, Terhadap Minat Muzakki Dalam Membayar Zakat Di Baitul Mal Kota Lhokseumawe.” Jurnal Ekonomi Regional Unimal 1, no. 3 (2018): $19-29$.

Fakhruddin, Muhammad. "ANALISIS PENGARUH TINGKAT PENGETAHUAN ZAKAT,TINGKAT RELIGIUS,TINGKAT PENDAPATAN,DAN TINGKATKEPERCAYAAN KEPADA BAZNAS TERHADAP MINAT MEMBAYAR ZAKAT PROFESI PARA PEKERJA ( STUDI KASUS PEKERJA DI DKI JAKARTA )." Skripsi (2016).

Ghozali, Imam. Aplikasi Analisis Multiverat Dengan Program SPSS. Semarang: 
Badan Penerbit Universitas Diponegoro, 2013.

Hasby Ash-Shiddiqy, Teuku Muhammad. Pedoman Zakat. Semarang: PT. Pustaka Rizki Putra, 2009.

Jena, Yeremias. FILSAFAT ILMU Kajian: Filosofis Atas Sejarah Dan Metodologi Ilmu Pengetahuan. Yogyakarta: Deepublish, 2015.

Jujun S. Suriasumantri. "FILSAFAT ILMU Studi Kasus: Telaah Buku Filsafat Ilmu (Sebuah Pengantar Populer) Oleh Jujun S. Suriasumantri.” FILSAFAT ILMU Studi Kasus: Telaah Buku Filsafat Ilmu (Sebuah Pengantar Populer) oleh Jujun S. Suriasumantri (2017): 0-23.

Karim, adiwarman a. EKONOMI MIKRO ISLAM. 5th ed. jakarta: Raja Grafindo Persada, 2015.

Muhyidin. "Pengaruh Citra Perusahan, Pengetahuan Produk Bank, Kepercayaan, Dan Pelayanan Terhadap Minat Menjadi Nasabah Bank Syariah Dengan Religiusitas Sebagai Variabel Moderating." S Salatiga, no. Fakultas Ekonomi dan Bisnis Islam IAIN Salatiga (2017).

Ram Al jaffri Saad, Kamil Md Idris, Zainol Bidin, RAJ Saad, KM Idris, and Z Bidin. "Peranan Sikap, Moral, Undang-Undang Dan Penguatkuasaan Zakat Terhadap Gelagat Kepatuhan Zakat Perniagaan.” International Conference on Corporate Law (ICCL) 2009, no. June (2009): 1-13.

Sari, Dia Oktavia. "Pengaruh Pemberian Pembiayaan Modal Kerja Terhadap Peningkatan Pendapatan Usaha Nasabah" (2017): 114.

Satrio, Eka, and Dodik Siswantoro. "Analisis Faktor Pendapatan, Kepercayaan Dan Religiusitas Dalam Mempengaruhi Minat Muzakki Untuk Membayar Zakat Penghasilan Melalui Lembaga Amil Zakat.” Simposium Nasional Akuntansi XIX 1, no. 4 (2016): 308-315.

Sugiono. Metode Penelitan Kuantitatif, Kualitatif Dan R\&D. Bandung: Alfabeta, 2016.

Suharyat, Yayat. "HUBUNGAN ANTARA SIKAP, MINAT DAN PERILAKU MANUSIA.” Jurnal region 1(3), 2009 1(3) (2009): Psikologi Komunikasi.

Sukirno, Sadono. MIKRO EKONOMI TEORI PENGANTAR. Tiga. jakarta: Rajagrafindo Persada, 2016. 
Nio Okta Nugraheni: Analisis Pengaruh Religiositas... $\mid 188$

Sumarwa, Ujang. PERILAKU KONSUMEN Teori Dan Penerapannya Dalam Pemasaran. Cet.4. Bogor: Penerbit Ghalia Indonesia, 2017.

Sumarwan, Ujang. Perilaku Konsumen (Teori Dan Penerapannya Dalam Pemasaran). Bogor: Penerbit Ghalia Indonesia, 2004.

Suwarto. "Dimensi Pengetahuan Dan Dimensi Proses Kognitif." Widyatama 19, no. 1 (2010): 76-91.

Syafiq, Ahmad (STAIN KUDUS). "Zakat Ibadah Sosial Untuk Meningkatkan Ketaqwaan Dan Kesejahteraan Sosial.” Ziswaf 2, no. 2 (2015): 380-400. 